\title{
Gaal György Brassai Sámuel és a kolozsvári egyetem
}

Gazdag múltja és irodalma van az erdélyi egyetemalapítási kísérleteknek. A fejedelemség korára három is esik. Mindhárom vezető felekezet megpróbálta itthon biztosítani fiataljai felsőfokú képzését. János Zsigmond az 1560-as években udvari orvosát, Blandrata Györgyöt bízza meg egy talán gyulafehérvári székhelyü akadémia terveinek kidolgozásával. Báthory István az 1579-ben Kolozsvárt felállított jezsuita iskolát 1581. május 12-én Vilnában kibocsátott alapítólevelével egyetemi rangra emeli, a diplomáit a külföldi egyetemekével egyenrangúvá nyilvánítja. Ez az intézet a vallási türelmetlenség miatt csak 1603-ig müködhetik, de mint középiskola később újraindult. Bethlen Gábor 1622-ben külföldi tanárok közremüködésével Gyulafehérvárt állít fel akadémiát. A háborús viszonyok ezt is elsöprik, de a reformátusok anyaiskolájaként - mint a nagyenyedi Bethlen Kollégium - máig él utódintézete. A jezsuita rend 1773-ban történt felszámolása után kolozsvári tanintézetükböl 17741775-ben Mária Terézia akart egyetemet kialakítani. Meg is vetette a jogi és az orvosi kar alapjait egy-egy tanszékkel. Talán a felekezeti nézetkülönbségek akadályozták meg a tényleges kibontakozást. Bár az intézmény neve Királyi Akadémiai Líceum lett, évtizedeken át többnyire „Universitas”-ként emlegették.

A Mária Terézia-féle kezdeményezésnek már van utóélete: a jogi kar $^{2}$ latin, német, 1842-től pedig magyar tannyelvvel az 1848-as forradalomig a Római Katolikus Líceum részeként müködik. Az 1850-es években azért nem indulhatott újra, mert az állam ragaszkodott a német tannyelvhez. Mikor az elnyomás enyhült, 1863-ban, mint Királyi Jogakadémia hat tanszékkel nyílt meg a régi helyiségekben. Az orvosi kar $^{3}$ 1817-ben kivált a líceum keretéböl, s mint Orvos-sebészi Intézet töretlenül fennáll 1872-ig. Épp e két karnak megfelelő akadémia, valamint az 1859-ben megalapított Erdélyi Múzeum-Egylet gazdag könyvtára és gyüjteményei biztosítottak kedvező keretet Kolozsváron a második magyar tudományegyetem felállításához. Az sem mellékes, hogy három felekezetnek, az unitáriusoknak, katolikusoknak és reformátusoknak több száz éves múltú középiskolái müködtek a városban.

A kiegyezés, valamint Erdély és Magyarország uniójának 1867-es törvénybe iktatása után nyilvánvalóvá vált, hogy Erdélyben kell a második magyar tudományegyetemet felállítani, s az is természetszerünek tűnt, hogy éppen Kolozsváron, a fökormányszék addigi székhelyén. A kiürülö hivatali helyiségek kínálkoztak az egyetem befogadására. Akkoriban úgy is emlegették, hogy Kolozsvár az addigi kormányszék helyett kárpótlásul kapta az egyetemet ${ }^{4}$. Ezután legalább szellemi főváros lehetett.

Az egyetem létesítésére 1867 októberében a jogakadémia teszi meg az első javaslatot a szakminisztériumnak. A továbbiakban Eötvös József vallás- és közoktatásügyi miniszter veszi át a kezdeményezést. Kikérve a jogakadémia és az Orvos-sebészi Intézet, tanári karának véleményét 1870. április 7-én terjeszt be törvényjavaslatot az egyetem felállítására. Eötvös halálát követően Pauler Tivadar veszi kezébe az ügyet. 1872. május 29-én eléri, hogy Ferenc József királyi beleegyezését adja az egyetem létesítéséhez. Június 11-én Lónyai Menyhért miniszterelnök Pauler közoktatásügyi és Tisza Lajos közlekedésügyi miniszterek társaságában Kolozsvárra látogat, s itt tájékozódik az egyetem elhelyezése felől. Ugyanaz nap megjelenik a

\footnotetext{
2 a magyar királyi jogakadémiák és joglíceumok története. Hivatalos adatok alapján. (Különlenyomat a Budapesti Közlönyből) Pest, 1873. 179-208.

${ }^{3}$ Maizner János, a kolozsvári Orvos-sebészi Tanintézet történeti vázlata 1775-1872. Kolozsvár, 1890.

${ }^{4}$ Kőváry László, a száz évet élt Dr. Brassai Sámuel pályafutása és munkái (1797-1897). Kolozsvár, 1897. 27.
} 
hivatalos pályázathirdetés a 42 tanári állásra. A több mint 120 jelentkezőből kiválasztott 34 rendes és 5 rendkívüli tanárt 1872. szeptember 29-én nevezi ki az uralkodó. Október 12-én az országgyülés elfogadja a XIX. és XX. törvénycikkelyt jóváhagyva az egyetem felállítását. Októberben még néhány utólagos kinevezés történik, s az egész tanári kar 19-én a katolikus líceum dísztermében Mikó Imre miniszteri biztos kezébe leteszi az esküt. Rögtön utána rektort és prorektort választanak, kijelölik a négy kar dékánját és prodékánját, ezek együttvéve képezik az egyetemi tanácsot ${ }^{5}$.

Mikor az egyetem-szervezés folyik, Brassai Kolozsvár, sőt Erdély legnagyobb tudósának számít. A forradalom előtt az Unitárius Kollégium tanára és igazgatója, lapszerkesztő, aztán közel tíz évig Pesten tanít $\mathrm{s}$ válik ismertté, 1859-től újra Kolozsvárt müködik, az Erdélyi Múzeum-Egylet igazgatója. 1865 óta a Magyar Tudományos Akadémia rendes tagja. Rajta kívül csak egy akadémiai rendes tag él még Kolozsvárt, Szabó Károly, a múzeumi könyvtáros. Természetesnek tünik, hogy mindketten tanszékhez jussanak. Brassai esetében azonban némileg csökkenti a kinevezés esélyeit a magas, 72 év körüli életkor.

Brassai mint a múzeum öre, majd igazgatója a Mikó-kertet botanikus kertté alakította, a Mikó-villát pedig tényleges múzeummá rendezte be. De ennek folyamán az egylet elnökével, Mikó Imrével és a melléje rendelt segédőrrel, Pávai Vajna Elekkel is konfliktusba keveredett, úgyhogy fontolgatta állásától való megválását. Amúgy is eltelt az a tíz-tizenegy év, amit Brassai egy-egy állásban eltöltött. Boros György Brassai-monográfiájában ${ }^{6}$ teljes egészében idézi a tudós 1870 júniusában Toldi Ferenchez intézett, a Magyar Tudományos Akadémia levéltárában őrzött levelét. Ebben leírja, hogy az 1850-es években „a nyelvhasonlítás kedvéért" miként tanult meg öneröből szanszkritul, miket olvasott e nyelven, s milyen ide vágó közleményei vannak. Majd elpanaszolja: „Nos, hát én abban a téves hitben leledztem, hogy az oktatásügyi miniszternek arról, hogy valaki egy ilyen ritka tárgyban tanulmányokat tett, lehetne sejtelme, még úgy is, ha nem volna Akadémia elnöke és nem ismerne személyesen." Elvárta volna, hogy a pesti egyetem szanszkrit tanszékének felállításakor őt is számításba vegyék.

Úgy tűnik, a kolozsvári polihisztort ekkoriban már illett meghívni valamely tanszékre. Kőváry László, Brassai első monografusa azt állítja, hogy még Eötvös József levélben szólította fel őt, válasszon tantárgyat a szervezésben levő egyetemnél ${ }^{7}$. Brassai hagyatékában ennek semmi nyoma. Boros György pályázati kérelmét sem találta az egyetemi levéltárban. Szinte biztosra vehető azonban, hogy az állások kiírása után Brassai is pályázott, s egyszerre több tanszéket is megjelölt ${ }^{8}$. Hiszen növénytanból, filozófiából, pedagógiából, a nyelvtudományokból országosan elismert tudós volt, matematikából inkább tankönyveit tartották számon. Ha mindezeket a tárgyakat megnevezte kérelmében, a tanszékeket elosztó Trefort miniszternek elég nagy gondot okozott. Talán ezzel is magyarázható, hogy a szeptember 29-én kinevezettek között nem szerepelt Brassai neve. Minden bizonnyal sorba betöltötték azokat a tanszékeket, amelyekre volt kellő felkészültségü jelentkező. Ott vették igénybe Brassait, ahol hiány mutatkozott. Így kapta az elemi mennyiségtan katedrát október 12-én. A kinevezés valószínüleg őt is meglepte, s csak részben egészítette ki. Úgyhogy ezáltal rosszul járt polihisztorságával.

\footnotetext{
5 Történelmi visszatekintés. A kolozsvári Magyar Királyi Tudományegyetem Almanachja MDCCCLXXIILXXIII-ról 3-7.; Márki Sándor, a M. Kir. Ferencz József Tudományegyetem története 1872-1922. Szeged, 1922. 31-7.; Makkai László, a kolozsvári M. Kir. Ferencz József Tudományegyetem története 1872-1919. Budapest, 1942. 3-7. (Különnyomat az Erdély magyar egyeteme. Bp., 1941. című kötetből.); Gaal György, Berde Áron útja a természettudományoktól a közgazdászatig. Kolozsvár, 1992. 33-8.

${ }^{6}$ Boros György, Dr. Brassai Sámuel élete, Cluj-Kolozsvár, 1927, 215-6.

${ }^{7}$ Köváry László i.m. 27.

${ }^{8}$ Non quis, sed quid?: Megjegyzések „Brassai százéves pályafutásá”-hoz. Erdélyi Múzeum 1897. 581-2.
} 
Talán, e tárgy mellett szól az, hogy Brassait 1837. szeptember 7-én az akadémia Matematikai és természettudományi osztályába választották levelező tagul, bár 1864 januárjában áttették a bölcseleti szakosztályba. Az Unitárius Kollégiumban is leginkább matematikát tanított. ő volt a szerzője-átdolgozója az első magyar nyelvü és még forgalomban levő tankönyveknek. Az angol mintára írt Számító Socrates (1842) és a kisdedek számvetése (1842) akkoriban a legelterjedtebb elemista tankönyv volt, az erdélyi iskolákban az 1890-es évekig használták őket. 1853-ban Pesten egy kétrészes Algebrai gyakorlatok és kulcsok címü könyvet tett közzé, 1872-ben pedig három népiskolai számtankönyve is sajtó alatt volt a fövárosban. Az akadémiában csak egyszer olvasott fel algebrai témájú dolgozatot (1857. március 16.), s magyarra fordította Euklidész müveit (1865).

Tény, hogy Brassai a többi professzorral együtt letett Mikó Imre kezébe az esküt, majd Unitárius kollégiumbeli tanítványát, tanártársát, a jogakadémiáról átjött Berde Áront megválasztották rektornak, őt pedig prorektornak. Az egyetem tényleges megnyitási ünnepségét november 10-én, vasárnap tartották a rektorbeiktatással összefüggésben. E napon a város, sőt Erdély örömünnepet ült: végre van egyeteme! Minden felekezet templomában hálaadó istentiszteletet tartottak, majd fél 12-kor a líceum II. emeleti termében a jogi kar dékánja, Groisz Gusztáv beiktatta Berdét, aki elmondta székfoglaló beszédét, kijelentve: „Uraim! egy új egyetem megnyitása áll előttünk. Önök tudják, hogy az egyetemet nem a néma falak, hanem a tanárok szellemi ereje alapítja meg jó hírnévben, áldásos „,működésben”. A Redutban, a város vigadójában tartottak díszebédet, melyen a környék minden müvelt értelmiségije, vezető embere részt vett, a pohárköszöntők sorát mondták. Este a Farkas utcai színházban került sor ünnepi előadásra: Vörösmarty Árpád ébredése címü darabjával kezdték a müsort. E. Kovács Gyula játszotta a föszerepet, azután élőkép következett a tudományok oltára címmel, végül Eötvös darabját, az Éljen az egyenlőséget mutatták be. Késő éjszakáig a várost kivilágították. A város érméket veretett e nap emlékére. Az ünnepségeknek mindenütt Berde volt a föszereplöje. ${ }^{9}$ Oldalán itt-ott megjelent Brassai is, bár kifejezetten vonakodott az ilyen alkalmaktól. Az 1860-as években Erkel Rózának panaszolta el, hogy a Magyar Orvosok és Természetvizsgálók vándorgyülése mind csak evés-ivásból áll, ha a többiek példáját követné, belebetegednék. ${ }^{10}$ 1890-ben az öt köszönteni készülő ifjaknak pedig azt üzeni: „Az ifjúságot mindig szerettem. A ceremóniát gyülölöm". ${ }^{11}$

Brassai tizenegy évig volt a Kolozsvári Magyar Királyi Tudományegyetem tanára. Ebböl öt éven át tisztséget is visel. Mégis a Brassai-életrajzok alig tudnak valami érdemlegest mondani erről a korszakáról, sőt az egyetemtörténeti összefoglalások sem részletezik professzori tevékenységét. Ennek két oka lehet. Brassai már elérkezett pályája hanyatló szakaszához. Az Unitárius Kollégium, az erdélyi sajtó, a Múzeum-Egylet történetébe korszakalkotóan írta be a nevét. Itt, az egyetemen inkább csodálták, mint követték. Másrészt nem olyan tárgyat tanított, amihez maga túlságosan vonzódott volna, vagy akkoriban az érdeklődés középpontjában állana. Évi tíz-tizenkét hallgatója ha akadt, szinte kivétel nélkül tanárjelöltek, akiknek célja nem a tudomány müvelése, hanem a diploma megszerzése volt.

Előadói munkásságát eddig csak Vályi Gyula, egyetemi tanítványa, tanszékének magántanára, később örököse jellemezte: „Brassai a kolozsvári tudományegyetemen ennek felállításától az 1882-83. egyetemi tanév végéig az elemi mennyiségtant tanította. Rendesen a téli félévben algebrát és geometriát, a nyári félévben trigonometriát és analitica geometriát adott elő.

\footnotetext{
${ }^{9}$ Az eseményekről részletesen beszámolnak a Kelet, Magyar Polgár, Kolozsvári Közlöny című napilapok 1872 október-novemberi számai, s ezek alapján Gaal György, I. m. 33-6.

10 Benczel Béla, Emlékezés Brassay [!] Sámuelre, aki négy hétig utazott Bécsbe, hogy egy koncertet meghallgasson. Ellenzék 1937. jan. 5.

${ }^{11}$ Brassai s az ifjúság tüntetése 1837-ben és 1890-ben. Ellenzék 1890. jún. 6.
} 
Időnként az algebra történetéről is tartott előadást. Előadásait világosság és kritikai irány jellemezte, mint általában egész tudományos müködését". ${ }^{12}$

Az egyetem az első tanévtől kezdve három sorozatban jelentette meg értesítőit. Az Acta a beszédeket tartalmazta, az Almanach az adattárat, a Tanrend pedig az előadások címét, karonként és tanáronként. ${ }^{13}$ Ezek Brassaira vonatkozó adatait talán elsőként hasznosítjuk. A Tanrend pontosan tájékoztat Brassai kurzusainak címéről, óraszámáról. Összehasonlítva más tanárokéval, Brassai kevesebb heti órát hirdetett. Mások tíz-tizenkét órát tartottak, Brassai többnyire hete, minden nap déli 12-1 óra között egyet-egyet. Hétfötől péntekig öt óra volt a kurzus, a szombati óra a gyakorlat. Ha valamelyik tanévben több órája volt, akkor hétfőn, kedden vagy csütörtökön délután 5 elött vagy után tartott egy-egy órát. Ezek színhelye mindig az X-es terem volt. A heti ötórás fő kurzusát nagyjából Vályi megállapítása szerint tartotta. A kurzusokhoz többnyire kétórás gyakorlat társult: hol „Elemi mennyiségtani gyakorlatok”, hol „Mértani gyakorlatok” címmel, később néha összevonva „Algebrai és geometriai gyakorlatok” szerepelnek a tanrendben. E gyakorlatokat „,különös tekintettel” a tanárjelölteknek ajánlották, akik az egyetemmel kapcsolatos „Tanárképezdé”-ben is kellett, hogy vizsgázzanak. Brassai különben tagja volt a Középtanodai Tanárvizsgáló Bizottságnak.

Érdekesebbek Brassai ritkán meghirdetett - ma is mondanók - speciális kurzusai. Mindössze négy esetben élt ezzel a lehetőséggel. 1876/77: Az egyenletek elmélete (II. félév heti 1 óra), 1877/78: Helyzettan - felsőbb geometria (I. félév heti egy óra), 1880/81 Mathézis történelme (I. félév heti 1 óra), 1882/83: Az algebra fejlődése a 4 utóbbi században (I. félév heti 1 óra). Pedig épp ezeken a szakkollégiumokon csillogtathatta volna tudást Brassai.

Egy 1882. december 8-án Gönczy Pálhoz intézett levelében így jellemzi tanítása módszerességét: „Nekem az a szokásom, hogy tanításom tervét egész iskolai évre egészen elkészítem a fejemben, és leckéimet mind tárgyban, mind felosztásban ahhoz szabom, úgy, hogy az előbbiekben előre készítem azt, amire a későbbiekben építek." ${ }^{14}$

Arra már Brassai első életrajzírója, egykori tanítványa, Kőváry László utal, hogy tantárgya nem elégítette ki „tanítási szenvedélyét”. ${ }^{15}$ Egy ehhez füzött megjegyzés az Erdélyi Múzeumban ${ }^{16}$ a Non quis, sed quid? álnév alatt (talán Szádeczky Lajos) arra utal, hogy Brassai 1874-ben át akarta magát helyeztetni a még mindig betöltetlen földrajzi tanszékre. Ezt az állítást Fitz József is leírja. Boros György szerint ,az áthelyezés iránti hajlandóságát nem lehet kétségbe vonni”, de az egyetemi levéltárban nincs nyoma ilyen irányú kérelemnek. Az Egyetemes és összehasonlító földrajz tanszékre 1874. július 31-én Terner Adolfot nevezték ki.

Több szerencsével járt Brassai egy másik próbálkozása. Ha már a fővárosi egyetemen nem vették igénybe szanszkrit tudását, kérte, hogy Kolozsvárt tarthasson előadásokat e tárgyból. A bölcsészeti karon több tehetséges hallgatóra, nagyobb érdeklődésre számíthatott, esetleg remélhette egy ilyen tanszék felállítását. Az 1875/76-os tanév végén Entz Géza rektor jelentésében ez olvasható: „az év folytában szaporodást nyertek az egyetemünkön képviselt tudományszakok az által, hogy Dr. Brassai Sámuel Mennyiségtan-természettudomány karbeli ny. r. tanár a szanszkrit nyelv és irodalomból tartandó előadásokra jogosíttatottt". ${ }^{17}$ Maga

\footnotetext{
${ }^{12}$ Vályi Gyula, Brassai, a matematikus. Kolozsvár 1890. máj. 24.

${ }^{13}$ Acta Reg. Scient. Universitatis Claudiopolitanae anni MDCCCLXXII-III. (Beszédek); a kolozsvári Magyar Királyi Tudományegyetem Almanachja MDCCCLXXII-LXXIII-ról; a kolozsvári Magyar Királyi Tudományegyetem tanrendje az MDCCCLXXII-III. tanév téli szakára \nyári szakára. (A cím 1881-től kiegészül Ferenc József Tudományegyetemre.) a továbbiakban: Acta, Almanach, Tanrend.

${ }^{14}$ Idézi Boros György i.m. 219.

${ }^{15}$ Kőváry László i.m. 27.

${ }^{16}$ Erdélyi Múzeum 1897. 581-2.

${ }^{17}$ Acta 1876-77. Fasciculus I. 6.
} 
Brassai inkább a ,szanszkrit nyelv és általános nyelvtudomány” megnevezését adta ${ }^{18}$ heti kétórás kurzusának. S bizonyára abból a rektori székfoglalójában említett fejlődőben lévő tudományágból is ízelítőt nyújtott, melyet általános nyelvtannak nevezett, s mely szerinte a filozófiával rokon, sőt nyelvfilozófiának tekinthető. ${ }^{19}$

Nem kizárt, hogy már az 1975/76-os tanév II. félévben hirdetett e tárgyból előadásokat, a Tanrendben azonban csak 1878/79 első szemeszterétől jelenik meg: Szanszkrit nyelv elemei nyelvészeti hasonlítással kísérve. Az előadás időpontját nem is jelölik ki - csak jelentkezés esetén kerül rá sor. Az 1879/80-as tanév elején így módosult a cím: Szanszkrit nyelv és irodalom ismertetése és az általános filológiára alkalmazása. A II. félévben elmarad a kollégium. 1880/81-ben mindkét szemeszterre a „Nalas” költői beszély magyarázatát ígéri. A következő két tanév első felében a „Nalaphakhyanam” olvasása a kitüzött feladat, a második félévre Szanszkrit nyelv és általános nyelvtudomány a kiírt kurzus címe. Az utóbbi cím 1882/83 mindkét félévben visszatér. Míg 1883/84 első szemeszterére így módosult: Szanszkrit nyelv és hasonlitó nyelvtan. Ez a félév már nyugdíjaztatása utánra esik, de úgy tünik, még két tanéven át Brassai folytatta nyelvészeti előadásait. 1884/85-ben Összehasonlitó nyelvtan és nyelvfilozófia címmel hirdet előadást a II. félévre.

Boros György idézi Borbély György magyar-latin szakos tordai unitárius tanár kézírásos visszaemlékezését: „Mikor én az egyetemre jártam, Brassai bácsi már nyugalmazott egyetemi tanár volt. Hanem azért mégis tartott egy líceumi előadást egy évig. Én is eljártam erre, mint minden olyanra, hol nem kellett fizetni. A nyelvészet filozófiáját vette elő és magyarázta. Volt erről egy nyomtatott könyv is, ezt hozta magával. Én azt hittem, hogy ezt a könyvet úgynevezett tankönyv gyanánt [ajánlja], ti. ő is tanul belöle, meg mi is tanulunk. De nem úgy volt. Az előadás egy kerek hétig a vezérkönyvnek csak a címlapjáról szólott. Le is szedte róla a keresztvizet alaposan.” Majd a teológus Boros hozzáfüzi: „Ezt a tudományos időtöltést mértékfelett élvezte Brassai, mert 8-10 hallgatója mindig volt. Többen hallgattunk nem egyetemi hallgatók is." ${ }^{20}$ Többnyire nem is a szanszkritért jártak Brassaihoz a bölcsészek, hanem, hogy hallják, lássák a legendás öreg tudóst. A szanszkrit és a nyelvtudomány nyugdíjas korában is foglalkoztatta Brassait. Naponta olvasott szanszkrit szöveget. Ritka gazdag szanszkrit könyvgyüjteményét az Unitárius Kollégiumnak hagyta.

Az egyetem első 40 fös tantestületéből csak 28-an voltak doktorok, jórészt a fiatalabbak. Az idősebbek ugyanis a régi rendszer szerint valamelyik kollégiumban elvégezték a filozófiai tanfolyamot, s utána egy-két évet egy külföldi egyetemre jártak, de diplomát nem szereztek. Brassai még ezzel a külföldi tanulmányúttal sem dicsekedhet. De ezeknek az idősebbeknek többnyire már az akadémia elismerte tudósi rangját. Az első tanári karból Brassai és Szabó Károly rendes, 5 másik tanár levelező tag volt. A doktorátus nélküli professzorokat az egyetem rendre tiszteletbeli doktori címmel tüntette ki. Az első tanévben sem a rektor, sem a prorektor nem volt doktor. Az 1873/74-es tanév végén Machik Béla rektort jelenti, hogy Berde Áron, Mina János, Brassai Sámuel, Koch Antal és Martin Lajos részére kiosztották a doktori oklevelet. ${ }^{21}$ Kőváry szerint az oklevelet 1874. január 27-ről keltezték. A címet Brassai ezután aláírásában is használta, büszke volt rá. ${ }^{22}$

Egy másik címmel már inkább gúnyolódott. A Bach-korszakban elterjedt a mind magasabb címzés, úgyhogy már nem is lehetett tudni, kit illet a tekintetes, nagyságos vagy méltóságos megszólítás. Brassai megelégedett az úr címzéssel, később többnyire Brassai bácsinak

\footnotetext{
${ }^{18}$ Például Szinnyei József Magyar irók élete és munkái I. kötetében (1891) így nevezi tárgyát.

${ }^{19}$ Acta 1879-1880. Fasciculus I. 69.

${ }^{20}$ Boros György i.m. 226.

${ }^{21}$ Acta 1874-1875. Fasciculus I. 10.

${ }^{22}$ Kőváry László i.m. 27. Vö. még Boros György i.m. 219. és Erdélyi Múzeum 1897. 581-2.
} 
szólították. Az 1860-as évektől Brassai kissé gúnyosan elkezdett mindenkit „Nagysád”-nak titulálni. A kiegyezés után a hivatalnoki ranglétrán a VI. fizetési osztályba soroltaknak járt ki a nagyságos cím. 1872-ben a kolozsvári professzorokat az alacsonyabbnak számít VII. osztályba soroltak be, míg a pesti egyetem tanárai a VI-ban voltak. Erre az egyetem harcba indult, hogy eltörölhesse ezt a különbségtevést. A miniszter 1873. február 1-i rendeletével meg is adták a kolozsváriaknak a VI. osztályú fizetést és vele a nagyságos címet. A városi polgárság ebből leginkább a címet észlelte, s gúnyolódott a nagyságos professzorok címkórságával. „A cím nyavalya. Régi nyavalya ez nálunk” - írta Brassai, s különösen akkor nevetséges, ha nem járul hozzá kellő vagyon. Ettől fogva Brassai még diákjait és házvezetőnőjét is nagyságolta. De azért nem vette rossz néven, ha őt így szólították meg. ${ }^{23}$

Brassai az egyetem tanácsában töltött öt év alatt mindegyik számításba jövő tisztséget viselte. Az első tanévben a helyetteseket is választották, így lett prorektor. Ezután mindig a rektor és a dékán a következő tanévre helyettes lett. Így biztosították a vezetés folyamatosságát, bár a prorektor, prodékán csak az azévi vezető akadályoztatása esetén jutott szerephez. Brassait 1879/80-ban rektorrá választották, s így 1880/81-ben újra prorektor lett. 1875/76-ban a Matematika-természettudományi kar dékánja, s ezt követően dékánhelyettes.

Mind dékánként, mind pedig rektorként mond egy-egy figyelemre méltó beszédet. Az akkori szokás szerint az évente megtartott pályázatra bejött dolgozatokat ünnepélyes keretben értékelték és díjazták, ugyanakkor kihirdették az új pályatételeket. Ezeknek az ünnepségeknek a bevezetőjében valamelyik dékán értekezést olvasott fel. 1875/76-ban a Matematikatermészettudományi karra esett a sor, s így Brassai tartott előadást. Nem kis meglepetésre, kara profiljának nem megfelelő tárgyról, a klasszikus nyelvek tanitásáról értekezett. ${ }^{24}$ Azért valamelyes aktualitása volt az eszmefuttatásnak: a reál tárgyak egyre inkább követelték helyüket a középiskolai tantervben. Márpedig ezek óraszámát csak a klasszikus nyelvek kiszorításával lehetett növelni.

Az értekezés nyomon követi, hogyan lett az ókori kultúra megismerésének eszközéül szolgáló latin nyelvböl, sőt a görögböl is cél. Mint ilyen túlzott helyet követelt magának. Miután a nemzeti nyelvek kifejlődtek, ezek irodalma megerösödött, a nemzetközi kapcsolatokban meg a francia terjedt el, nem indokolt a klasszikus nyelvekre fordított óraszám. Az értelmi fejlesztésre a modern nyelvek és a reál tárgyak is szolgálhatnak. Így összegez: „Véleményem szerint a görög-latin nyelv tanításának a gimnáziumban más célja nincs és nem is lehet, hanem csupáncsak az, hogy a fiatal nemzedéknek kulcsot adjunk a kezébe a klasszikus remekeknek értelmi felnyitására." Többen tévesen úgy értelmezték ezt a beszédet, mintha Brassai a klasszikus nyelvek teljes kiiktatását pártolná. Valójában csak gyors, praktikus kis óraszámú tanításukat javasolja, hogy így a diák képes legyen a klasszikusokat olvasni. Mert az ókori szerzők erkölcsi tanítása nem nélkülözhető.

Az 1879/80-as tanév elején elmondott rektori programbeszédét ${ }^{25}$ mentegetőzéssel kezdi: „Kérem a tisztelt tanári testületet, ne ítéljen el engemet, hogy aggott koromat nem tekintve elfoglalom ezt a tisztelt helyet." Majd említi, hogy kellemesen meglepte, mikor hírét hallotta a megválasztására irányuló mozgalomnak. Ezúttal az egyetemi tanár teendőiről értekezik. Hosszasan vázolja a német professzorok felolvasó-diktáló módszerét, a franciák fárasztóbb rögtönző stílusát, az angolokét is, s megállapítja, hogy sehol sem kötelessége a tanárnak a kutatás, melyre legkifejezőbb szóként az angol „research”-öt használja. Aztán végig veszi a tudományok egész rendszerét a teológiától az orvostudományon át az egzakt diszciplínákig, $\mathrm{s}$ mindenütt kiemeli a még kutatható ágazatokat. Leszögezi: a kutatásra nem lehet kényszeríteni

\footnotetext{
${ }^{23}$ Mikó Imre, Az utolsó erdélyi polihisztor. Bukarest, 1971. 276-7; Erdélyi Múzeum 1897. 581-2.

${ }^{24}$ Acta 1875-1876. Fasciculus II. 7-33.

${ }^{25}$ Acta 1879-1880. Fasciculus I. 47-87.
} 
a tanárt, ez csak önkéntes szabad müvelet lehet, s csak úgy eredményes, ha az illető élvezi a találmány gyönyörét. Csak az ilyen tanár tudja valóban az újat terjeszteni. Egy szemléletes hasonlattal írja körül a kutatás feltételeit: nem lehet úgy kutatni, mint ahogy a bajadér táncol impresszáriója ostorától félve, hanem „mint az a romlatlanul kifejlett leány, kinek ártatlan kíváncsiságát a korai [...] gyermekbálok el nem vásolták, élvezi táncát az első bálban, ahová vitték". Éppen azért elveti a pályázatok rendszerét is, mert díjért, versenyezve nem lehet újat teremteni.

Ez a gondolat visszatér a májusi díjkiosztó ünnepély bevezető beszédében is, amikor arra figyelmeztet, hogy a díjak csak a kidolgozók haladását bizonyítják, nem a tudományét is. ${ }^{26}$ Rektori beszámolójában ${ }^{27} 1880$ szeptemberében felsorolja az előző tanévre vonatkozó fontosabb adatokat. Így megtudjuk, hogy 41 rendes, 1 rendkívüli, 1 helyettes tanára, 5 magántanára, 1 előadója, 3 magántanítója, 16 tanársegéde valamint 4 mütőnövendéke volt az egyetemnek. Az I. félévre 462, a II-ra 477 diák diák iratkozott be. Tudatja, hogy az egyetemi tanács véleményt nyilvánított a nők érettségiztetésével kapcsolatban: a nők érettségire bocsáthatók. Brassai különben pályája legelején föúri családoknál leánynevelö volt vagy tizenegy évig, s azóta nagyra becsülte a nők szellemi képességeit.

Feltehetően rektorként ismerte meg jobban Brassai az egyetem és a diákság anyagi helyzetét és az akkor még kis számú alapítvány jelentőségét. Mindig híres volt adakozó természetéről, különösen egykori iskolája $\mathrm{s}$ nem egy tanítványa részesült ismételten támogatásban. A kollégiumi fizika szertár felszerelésére ezernél több forintot költött, tanítványa, Berde Áron külföldi képzését pedig 180 forinttal támogatta. A rektorságról leköszönve az egyetemnél is alapítványt tett. Méghozzá nem általában a diákok, vagy az ő karán tanulók valamelyikén akart segíteni, hanem a tudósképzést támogatta. Azt szerette volna, hogy vizsgaköltség ne legyen akadály a doktorátusra jelentkezésnél. Az 1880/81-es Almanach-ban ezt olvassuk: „11. Fundatio Brassaiana. Alapítója dr. Brassai Sámuel, egyetemünk ny. r. tanára, 1881. január hó 25-én kelt alapító oklevelével 200 forintnyi alapítványt tett oly célból, hogy ez összeg mindaddig, amíg az a maga, s netalán másoknak is hozzájárulásával, valamint a kamataival 1000 forintra szaporodik, kamatoztassék, azután pedig, amikor ez alapítvány 1000 forintra emelkedett, annak kamataiból a matematika-természettudományi karban todori szigorlatot tevő oly szegénysorsú ifjaknak a szigorlati költségei fedeztessenek vagy pótoltassanak, akiket a matematika-természettudományi kar arra érdemesnek ítél. Az egyetemi tanács az alapítványt 1881. évi január 29-i ülésében elfogadván, annak a „Fudatio Brassaiana” nevet adta; egyszersmind az alapítvány tételéröl a $\mathrm{nm}$. vallás- és közoktatásügyi miniszter urat értesítvén, ő nagyméltósága azt 3864-881. szám alatt kelt leiratával köszönetének kifejezése mellett örvendetesen tudomásul venni méltóztatott. Az alapítványt a questura kezeli." ${ }^{28} \mathrm{Ez}$ az akkor még fiatal egyetem történetében a 11. Alapítvány volt. Haller Károly rektori beszámolója így említi az alapítványt: „Dr. Brassai Sámuel tanár úr mint egyetemünk volt nagyságos rektora múlt évi beszámolója alkalmával tett alapítványát befizette, s kamatoztatása megkezdetett. Legyen a nemeslelkü adományozónak e helyen is az egyetem hálás megemlékezése biztosítva." 29 Az 1870-es évektől Brassai a város, az egyetem, az unitárius egyház nagy öregje, akit minduntalan ünnepelnek, akinek a neve fogalom és szimbólum. Az egyes társaságok, intézmények rangjukat emelik azzal, hogy rendes vagy tiszteletbeli tagjaik sorába iktatják. 1877 februárjában tanárrá választása 40. évfordulóján az Unitárius Kollégium elöljárósága tiszteleg Brassai előtt, aki az iskola felügyelő gondnoka is. Az Unitárius Főtanács

\footnotetext{
${ }^{26}$ Acta 1879-1880. Fasciculus II. 5-7.

${ }^{27}$ Acta 1880-1881. Fasciculus I. 3-19.

${ }^{28}$ Almanach 1880-1881. 51.

${ }^{29}$ Acta 1881-1882. Fasciculus I. 26.
} 
még abban az évben örökös felügyelő gondnokká választja. ${ }^{30}$ a Marosvásárhelyen megalakuló Kemény Zsigmond Társaság 1877 júniusában az elsők között iktatja tagjai sorába. ${ }^{31}$ a MajnaFrankfurtban székelő Freies Deutsches Hochstift 1878-ban a svéd királlyal egyszerre választja tiszteletbeli tagjául. ${ }^{32} \mathrm{Az}$ már szinte említésre sem méltó, hogy 1878 októberében a Tiszafüred-vidéki Régészeti Egylet is tiszteleti tagsággal tünteti ki. ${ }^{33}$

A legemlékezetesebb évfordulós ünnepségre 1879. Augusztus 5-én kerül sor. Ekkor telt el 40 éve, hogy az Araliaceaek egy Ausztráliában élő fajtáját Brassairól nevezték el. Ez olyan rendkívüli esemény volt, amelyre Kanitz Ágost, az egyetem botanikus professzora albumot állíttatott össze, s ünnepélyes keretek közt nyújtották azt át Brassainak szerény Monostor úti lakásán. Íme, Imre Sándor rektori beszámoló beszédének ide vágó sorai: „Itt lesz helye megemlítenem, hogy tisztelt társunkat, Brassai Sámuelt, az egyetem megválasztott rektorát, a haza és külföld természettudósai részéről ritka megtiszteltetés érte. Ti. mintegy 80 szaktudós Európa minden országából tisztelte meg üdvözlö írással, fényképével, annak az érdekes eseménynek 40 éves fordulónapjára, melyen néhai Endlicher István nagyérdemű növénytudós egy újhollandi növényt t. kartársunk nevével jelelt meg. A megtisztelő fényképalbum, a szaktudósok arcképei gyüjteménye, folyó évi augusztus 5-én adatott át magánkörben a megtisztelttel legszorosabb s legrégibb kapcsolatban álló testületek képviselöi jelenlétében. De a magános ünneplés oka és tárgya minket is mélyebben érdekel, mintsem itt elhallgathattuk volna." ${ }^{34}$ a fehér bőrkötéses albumban Köváry szerint ${ }^{35}$ többek közt 5 angliai, 2 belgiumi, 8 franciaországi, 3 németalföldi, 7 németországi, 10 itáliai, 1 orosz, 1 spanyol, 1 svájci tudós szerepelt arcképpel és néhány elismerő sorral. A 32 magyar tudós közül kiemeli Haynald bíborost. A köszöntőbeszédet Kanitz Ágost latinul mondta felsorolva Brassai botanikai eredményeit, erre az ünnepelt is latinul válaszolt. Majd Kovácsi Antal az 1839-beli tanítványok nevében köszöntötte Brassait. Ferencz József unitárius püspök az egyház és az iskola háláját tolmácsolta. A várost Simon Elek polgármester az Erdélyi Múzeum-Egyletet Finály Henrik, az egyetem matematika-természettudományi karát pedig Entz Géza dékán képviselte. Úgyhogy az ünnepség nem is volt olyan szükkörü. ${ }^{36}$

Kőváry szerint Brassai füvészként volt a legismertebb, ilyen irányú társasági tagságai, kitüntetései is erre utalnak. ${ }^{37}$ Kanitz Ágost az általa alapított Magyar Növénytani Lapokban 1887-1889-ben rendre közölte a Brassai és a Kováts Gyula által 1858-ban összeállított Új magyar füvészkönyv fejezeteit. Megállapította: „Nem nyomhatom el azon őszinte meggyőződésemet, hogy növénytani irodalmunkra nézve valóban nagy veszteség, hogy a munka 1858-ban kész részei nem jelentek meg."38

Ha nem legkedvesebb tárgyát tanította is, Brassai jól érezte magát az egyetemen. Tanártársai közül - akik különben mind gyermekei és tanítványai lehettek volna - többeket baráti körébe fogadott. Különösen jó viszony füzte Concha Győző, Farkas Lajos, Felméri Lajos, Kanitz Ágost, Finály Henrik, Szabó Károly professzorokhoz. Ezekkel szívesen vitatkozott

\footnotetext{
${ }^{30}$ Boros György i.m. 201.

${ }^{31}$ a marosvásárhelyi Kemény Zsigmond Társaság levelesládája. Sajtó alá rendezte és jegyzetekkel ellátta Marosi Ildikó. Bukarest, 1973. 407-8.

${ }^{32}$ Fritz József, Brassai Sámuel. Új kiadás. Budapest, 1912. 306.

${ }^{33}$ Kőváry László i.m. 29.

${ }^{34}$ Acta 1879-1880 Fasciculus. I. 8.

${ }^{35}$ Kőváry László i.m. 29.

${ }^{36}$ Az únnepség leírását és az eéhangzott beszédeket közli P. [Péterfi Dénes] a Keresztény Magvetőben: $D r$. Brassai Sámuel. 1879. 265-269.

${ }^{37}$ Kanitz Ágost, Brassai, a botanikus. Kolozsvár, 1890. máj. 24.; Kőváry László i.m. 65-66.

${ }^{38}$ Töredék a Brassai - Kováts-féle „Új magyar füvészkönyv”-böl (1858). Magyar Növénytani Lapok 1886. $17-$ 45. [Lapalji jegyzet]
} 
szaktárgyaikról, elfogadta meghívásaikat családi otthonukba. Boros György teológiai tanár szintén a baráti kör tagja, igen találóan jellemzi Brassai és az egyetem viszonyát:

„A Tudományegyetem és az egyetemes tudós Brassai kitünően összeillettek. Az ifjú egyetem az öreg kétemeletes gubernális épületben helyezkedett el, ugyanott, hol most a fóépület van. Brassainak tudományban megőszült feje korhű dísze volt a régi, masszív, szintén megöregedett nagy épületnek."

„Ha a vizsgákon tanárhiány mutatkozott, Brassaihoz izentek, s ő helyt állott, ha kellett francia nyelvböl, ha szükséges volt, más tárgyból is. Az egyetem szívósan ragaszkodott érdemes tagjához. A tanárságban kortársai, valamint a fiatalok is olyan oszlopnak tekintették, amelyről az egyetem tudományos jellege mindenkinek szemébe ötlik. Csak őt kellett látni, s már azonnal észrevehető volt, hogy a kolozsvári egyetem nem olyan fiatal, amilyent évei mutatnak. Hammurabi törvényoszlopa vagy Mózes kőtáblája nem fejezte ki hívebben a király, illetőleg Isten szándékát, mint ez a bölcs Mózes, aki fölment népével a Nebo hegyére, és onnan megmutatta a tudománynak gazdagon termő Kánaánját." 39

Túl a 80. életévén Brassai még tökéletes szellemi frissességnek örvendett. Hanem a testen már jelentkeztek az öregedés jelei. Előbb hallása romlott meg, hangja remegővé vált, ami nehezen érthetővé tette amúgyis hadaró beszédét, keze kissé reszketett. Mindez még nem akadályozta a tanításban, eszébe sem jutott nyugalomba vonulni. Az 1881/82-es tanév végén, mint Ajtai Sándor rektor jelentéséből kitünik, Brassai „egészsége helyreállítása végett” két és fél hónapos szabadságot vett ki. ${ }^{40}$ Arra a félévre kiírt előadásait előzőleg megtartotta, így nem kellett helyettesíteni. Boros György szerint csak az utazási vágy vett eröt Brassain, s orvosa, Brandt professzor is ajánlatosnak látta a levegőváltozást. Hanem akkoriban az ilyen szabadságolásokat maga a miniszter hagyhatta jóvá s rossz ómennek számítottak. Csak legvégső esetben folyamodtak hozzá a professzorok, többnyire rövidesen bekövetkezett nyugdíjazásuk, haláluk. A minisztériumban ez a szabadságolási kérelem is azt a benyomást keltette, hogy eljött az ország akkori legidősebb egyetemi tanárának a nyugdíjazási ideje. Ráadásul tanszékének betöltésére két jelölt várt, a tanítvány-magántanár Vályi Gyula és az elméleti fizika professzora, Réthy Mór. Az utóbbi országosan ismert matematikus volt, 1878ban az Akadémia is levelező tagjai sorába választotta, később Bolyai hagyatékénak kutatójaként tünt ki. Réthy a fövárosban kitünő kapcsolatokkal rendelkezett, mert mint az 1873/74-es rektori beszámolóból kitünik ${ }^{41}$, a kar megkérdezése nélkül nevezték ki Kolozsvárra rendkívüli tanárnak. (Akkor fejezte be doktorátussal heidelbergi tanulmányait.) Réthy a fizikát csak kényszerből müvelte, s időnként matematikai kurzusokat is hirdetett. Valószínü, hogy igyekezett sürgetni a fövárosban Brassai nyugdíjaztatását.

Trefort Ágost miniszter először 1882 nyarán írt az egyetem rektorának, hogy ha Brassai „maga is szükségét érzi a nyugalomba lépésnek, s ha erről a rektor és az egyetemi tanács is úgy van meggyőződve", kérjék fel ez irányú iratainak benyújtására. A miniszter ígéri: teljes fizetéssel nyugdíjazzák. Brassai azonban az ügyet egyre halasztotta. Mikor Gönczy Pál miniszteri tanácsos decemberben újra érdeklődik Brassai szándéka felől, ez magyarázkodó levelet küld. Végül engednie kellett a több irányból jövő unszolásoknak. Mint Boros György kimutatja, Brassai kéréséhez munkaigazolványokat is mellékel: 14 év 10 hónap 22 nap középiskolai tanárságról és 11 évi egyetemi szolgálatról. Úgyhogy téves az a többször elhangzó állítás ${ }^{42}$, mely szerint Brassai megkérdezése nélkül küldték volna nyugdíjba.

\footnotetext{
${ }^{39}$ Boros György i.m. 227.

${ }^{40}$ Acta 1882-1883. Fasciculus I. 14.

${ }^{41}$ Acta 1874-1875. Fasciculus I. 9.

${ }^{42}$ Kőváry László i.m. 30.; Gál Kelemen, Brassai Sámuel. Cluj-Kolozsvár, 1926. 9.
} 
Érdekes módon itt is, akárcsak a többi állásában, 11 évet töltött. A jóbarát és pályatárs, Szabó Károly leköszönő rektor így emlékezik meg az eseményröl:

„Dr. Brassai Sámuel, az elemi mennyiségtan nyilv. [ános] rendes tanára őfelsége f[olyó] évi júl[ius] 23-án kelt legfelsőbb elhatározásával teljes egyetemi tanári fizetésének élvezése mellett nyugalomba helyeztetett $\mathrm{s}$ egyszersmind hosszú közpályán a tudomány mívelése és terjesztése körül szerzett kiváló érdemei elismeréséül kir[ályi] tanácsosi címmel díjmentesen ruháztatott fel. Egyetemünk tanári karának köztiszteletben álló Nestora, a tudományos világban általánosan ismert nevű ősz tudós, a múlt tanév végén eszerint megvált tanszékétől, melyen ifjúsága óta, nemzetünk értelmességének fejlesztésére oly buzgón s oly sikeresen müködött: de nem szünt meg egyetemünk tanári karának dísze, büszkesége, irodalmunk munkása lenni, ki korához képest bámulatosan ifjú szellemi erejével hivatva van a tudományos irodalom oly különböző térein egyaránt kitűnő hatással müködni, s ezáltal érdemeihez érdemeket füzni, s egyetemünkre, mely őt legérdemesebb tagjának ismeri, újabb fényt vetni." 43

A Matematika-természettudományi kar Martin Lajos dékán aláírta levélben vesz búcsút a professzortól ebben megállapítja: „Azon tizenegy év, melyet szerencsénk volt Nagyságoddal együttmüködve ifjú egyetemünkön átélni, bő alkalmat nyújtott mindnyájunknak Nagyságodban nem csupán a tanácsban bölcs kartársat $\mathrm{s}$ a tudományos munka terén fennkölt szellemü zászlóvivőt tisztelni, hanem egyszersmind személyéhez közelebb jutva, szívben nemes barátot szerezhetni." ${ }^{, 4}$ a dicséretek és kitüntetések ellenére is Brassainak fájt kierőszakolt nyugdíjaztatása. A királyi tanácsosi címet soha sem használta.

Brassai tanszékét egy évig a felsőbb matematika professzora, Martin Lajos és Vályi Gyula magántanár helyettesként látta el, majd 1884/85-től Réthy Mórt áthelyezték az elemi mennyiségtan tanszékre, Vályinak be kellett érnie az elméleti fizikai tanszékkel. Mikor aztán 1886-ban Réthy a budapesti müegyetemre távozik, Vályi lesz a matematika tanára. ő is a Bolyai-kutatással szerez érdemeket.

Brassai még két évig megtartotta nyelvészeti óráit, ha akadt jelentkező. Aztán jóformán minden kapcsolata megszakadt az egyetemmel, mint intézménnyel. De nem a baráti körébe tartozó tanárokkal. Mikor 1890 júniusának elején 90. születésnapja alkalmából az akadémia Eötvös Lóránd és Szily Kálmán fötitkár aláírta levélben üdvözli az Unitárius Főtanács pedig testületileg vonul lakására, hogy köszöntsék, az egyetem nem képviselteti magát. Csak mikor már halálos ágyán fekszik, s híre kél századik születésnapjának, tiszteleg küldöttségileg az egyetemi tanács. Ekkor is főleg annak köszönhetően, hogy épp Farkas Lajos, a római jog professzora, Brassai szükebb baráti körének tagja a rektor.

Június 3-án a már halálát közeledni érző Brassai az őt meglátogató Kőváry Lászlónak és Szabó Samunak úgy nyilatkozik, hogy 1797. június 15-én született. Ezek az addigi bizonytalan 1800 első felére eső születési dátummal szemben ezt hitelesnek tekintették, s közhírré tették. Olyan nagy visszhangja lett a dolognak, hogy maga az uralkodó is gratulált. „Június 15-e nagy ünnepe volt a nemzetnek. Egyetlen ünnepnapja a nagy magyar tudósnak, ki száz éven át csak munkanapokat ismert." - írja Kőváry. ${ }^{45}$ a tisztelgők sorában megjelent a Ferenc József Tudományegyetem háromtagú küldöttsége is: Farkas Lajos rektor, Márki Sándor és Farkas Gyula dékánok. A rektor a dátum helyességében kételkedők közé tartozott, $\mathrm{s}$ ezt szavaiban is kifejezte: „Nem az igazi nap a mai, de azért mi is kívántuk a mi mély és igazán őszinte jókívánatunkat kifejezni, s kívánjuk, hogy az igazit az általunk tervezett módon, és nem így az ágyban, megünnepeljük.” Brassai rövid válasza: „Igazán fájdalmas

\footnotetext{
${ }^{43}$ Acta 1883-1884. Fasciculus I. 7.

${ }^{44}$ Boros György i.m. 226.

${ }^{45}$ Kőváry László i.m. 41. A következő idézetek is innen vannak.
} 
betegségben vagyok; nehezen tudom összeszedni gondolataimat. De annyit mégis elmondhatok, hogy nagy örömöt okoz nekem az én kedves kollégáimnak a megemlékezése, akiket mindig nagyon szerettem. Ha jobban leszek, másképpen is meg fogom hálálni.”

Az országos ünneplést csak kilenc nappal élte túl Brassai. Június 24-én reggel „a kolozsvári Vöröskereszt Kórházban az élök közül a halhatatlanok sorába költözött át" - mint írta az Erdélyi Múzeum búcsúcikke. ${ }^{46}$ a hír órák alatt bejárta a várost, megtörténtek az előkészületek a nagy temetésre. Farkas Lajos rektor is összehívta az egyetemi tanácsot, s rövid beszédben jelentette be a szomorú hírt. Megállapítja, hogy a nemzeti történetírás feladata lesz e tüneményszerü egyéniség életpályáját megrajzolni. „De azt már éreztük és világosan tudtuk, hogy a csaknem százéves élet minden napja az igaznak és jónak nemcsak fáradhatatlan keresésében, munkálásában, hanem a belőle megtaláltnak kicsinnyel és naggyal egyaránt önzetlen megosztásában telt el." ${ }^{, 47}$ Brassai emlékét jegyzőkönyvileg örökítik meg, és elhatározzák, hogy latin és magyar nyelvü gyászjelentést adnak ki, a ravatalra koszorút tesznek, s a tanács a temetésen szokásos díszöltözékében és jelvényeivel fog megjelenni.

A temetést az Unitárius Egyház a templomból rendezte. Ott csak Ferencz József püspök mondott beszédet és imát. A küldöttségek a Házsongárdi temető sírjánál jutottal szóhoz. Itt az egyetem részvétét a Mennyiségtan-természettudományi kar dékánja, Farkas Gyula tolmácsolta. ${ }^{48}$

A százéves születésnap hírén felbuzdulva a torockószentgyörgyiek elhatározták, hogy emléktáblával jelölik meg a helybéli papi lakot, a feltételezett szülőházat. A tábla leleplezésére július 18-án került sor. Megint minden érdekelt fórum elküldte képviselőjét, akik beszédet is mondtak. Az akadémia elismerését Márki Sándor, az egyetemét Szádeczky Lajos, az Erdélyi Múzeum-Egyletét Apáthy István tolmácsolta, mindhárman az egyetem legjelesebb professzorai. Márki megállapítása: „Apáczai és Brassai Magyarország legnagyobb két enciklopédistája. Kétszáz esztendő választja el müködésüket, talán csak araszni köz sírjaikat, egy pókháló szála sem föladataik tömegét.”49

Farkas Lajos rektor a tanév végi beszámolójában három jeles professzor haláláról is megemlékezik. Mindhárman az alapítók nemzedékéből valók: Martin Lajos, Szilasi Gergely, Brassai Sámuel. A legtöbbet Brassaival foglalkozik, felsorolja egyetemi tisztségeit, $\mathrm{s}$ ugyanazokkal a szavakkal méltatja, mint a halálát követő rendkívüli tanácsülésen. ${ }^{50}$

Még egy feladat maradt: Brassai emlékének megörökítése. Arcképét még korábban, mikor az egyetem megnyitásának tizedik évfordulóját ünnepelték, a többi rektoréval együtt Veress Ferenccel porcelánba öntették, és a tanácsteremben helyezték el. ${ }^{51}$ Most a sajtóban olyan javaslat is elhangzott, hogy az éppen készülő új egyetemi épület elé Brassai-szobrot kellene felállítani. ${ }^{52}$ Legsürgősebb feladat azonban sírja megjelölése volt. A kezdeményezés Farkas Lajos rektor nevéhez füződik, aki július 9-ére tanácskozást hívott össze ebben a tárgyban. ${ }^{53}$ Ezen az egyetem néhány professzorán kívül részt vettek a város és az Unitárius Egyház

\footnotetext{
${ }^{46}$ Brassai Sámuel. Erdélyi Múzeum 1897. 402-12.

${ }^{47}$ Kőváry László i.m. 50. A teljes beszédet közli.

${ }^{48}$ a temetés leírását közli az Ellenzék c. napilap 1897. jún. 28-i száma, valamint Gaal György, Aki egy század tudományosságát átfogta: Brassai Sámuel. Erdélyi Református Naptár az 1997. évre. Kolozsvár, 1996. 203-7.

49 a torockói ünnepségről beszámol az Ellenzék július 19-20-i számaiban, továbbá az Erdélyi Múzeum 1897. 402-412. lapjain, innen a Márki idézet. A tábla felirata: „E házban / 1797. év június 15-én született / Dr. Brassai Sámuel. / e kölappal a tudósok öregének emlékét nemzeti / kegyelettel örökíti e község közönsége 1897. évben.”

${ }^{50}$ Acta 1897-1898. Fasciculus I. 21-22.

${ }^{51}$ Acta 1881-1882. Fasciculus I. 15.

${ }^{52}$ Ürmössy Lajos, Brassai-emlék. Ellenzék 1897. júl. 13.

${ }^{53}$ a síremlék-állítás minden adata megtalálható a következő, valószínüleg Boros György összeállította füzetben: Brassai Sámuel sirremléke. Átadási ünnepély. 1910. október 2. Kolozsvár, 1910.
} 
képviselői. Elhatározták, hogy közadakozásból emelnek méltó emlékmüvet, s létrehoztak egy 89 tagú országos bizottságot. A tényleges gyüjtés, kivitelezés az intéző bizottságra hárult, melynek elnöke Farkas Lajos, titkára Boros György teológiai tanár, pénztárosa pedig Merza Lajos lett. A legelső adományt Duka Tivadar küldte Londonból. Csak 1910-re gyült össze annyi pénz, hogy a munkálatokhoz kezdjenek. Pákey Lajos egyik klasszicizáló tervét választják ki, rajta Brassai másfélszeres bronz mellszobrával. Az 1910. október 2-i leleplezéskor Farkas Lajos méltatta Brassai egyéniségét és vázolta az életmü történetét. Az egyetem nevében Szádeczky Lajos rektor, a Matematika-természettudományi kar nevében pedig Fabinyi Rudolf dékán helyezett el koszorút. A szoborbizottság elnöke, Farkas Lajos nem fogadta el az 1797-es születési évszámot, így 1800-at vésetett bele. A szobor mögötti hátlapra ezt megerősítendő odaíratta:

\section{„A százzal haladóknak” \\ A nemzeti kegyelet \\ 1910}

Brassai a kolozsvári egyetemalapító tanári kar legidősebb, legsokoldalúbb és leghíresebb tagja volt. Pályája alkonyán és a nem a neki leginkább megfelelő tudomány képviseletében került az egyetemre, így - bár minden szinten kivette részét az egyetemi munkából, vezetésből különösebb hatást nem fejtett ki, iskolát sem alapíthatott maga körül. Az egyetem történetébe külön színt képviselnek szanszkrit és általános-összehasonlító nyelvészeti órái. Ezeken egyéniségének megfelelő, őt foglalkoztató és kora tudományosságának szintjén álló ismereteket továbbíthatott. 